\title{
UKRAINIAN POPULATION OF CRIMEA IN 1989-2014: SPECIFICS OF DEMOGRAPHIC TRANSFORMATIONS ${ }^{1}$
}

\author{
(C) Dmitry I. Uznarodov
}

\author{
Federal Research Centre the Southern Scientific Centre of the Russian \\ Academy of Sciences, Rostov-on-Don, Russian Federation \\ uzn-dmitrij@yandex.ru
}

The specificity of the demographic transformations of the Ukrainian population of Crimea in the period from 1989 to 2014 is considered. Based on the analysis of the population censuses of 1989,2001 and 2014, demographic changes within the Ukrainian ethnos are revealed during two periods: from 1989 to 2001 and from 2001 to 2014. The analysis of changes in the number of the Ukrainian ethnic group in the context of the municipalities of the Crimean Peninsula is carried out. It is concluded that the percentage of the Ukrainian ethnic group in the structure of the population of the Crimean Peninsula, which we could observe in the period from 1989 to 2001 , was formed as a result of the policy of resettlement of citizens to this region in the late 1940-s and early 1950-s from various republics of the Soviet Union, mainly the RSFSR and the Ukrainian SSR. It is noted that the regions with the maximum number of the Ukrainian ethnic group are historically located in the northern regions of the Crimean Peninsula, and with the smallest - in the southern regions. The study showed that changes in the ethnic structure began to occur after the events of 2014 and the entry of Crimea into the Russian Federation, when, according to the 2014 population census, the number of Ukrainians in the republic, compared to 2001, decreased by almost $9 \%$. According to the analysis, if in the period from 1989 to 2001 the maximum scale of the decrease in the number of the Ukrainian ethnic group took place in the central part of the Crimean peninsula, then in the period from 2001 to 2014 the largest scale of the decrease in the number of the Ukrainian ethnic group was observed in the municipalities of the northern part of the Republic of Crimea, which, in our opinion, this is mainly due to the outflow of the population from these territories, due to the negative reaction of some Ukrainians to the events of the "Crimean Spring" 2014.

Key words: Crimean Peninsula, Ukrainian ethnic group, population, demography, ethnic structure.

\section{[Д.И. Узнародов Украинское население Крыма в 1989-2014 гг.: специфика демографических транс- формаций]}

Рассматривается специфика демографических трансформаций украинского населения Крыма в период с 1989 по 2014 гг. На основе анализа данных переписей населения 1989, 2001 и 2014 гг. выявляются демографические изменения внутри украинского этноса на протяжении двух периодов: с 1989 по 2001 гг. и с 2001 по 2014 гг. Проводится анализ изменения численности украинского этноса в разрезе муниципальных образований Крымского полуострова. Делается вывод, что процентное соотношение украинского этноса в структуре населения Крымского полуострова, которое мы могли наблюдать в период с 1989 по 2001 гг., было сформировано в результате проводимой властями страны в конце 40-х-начале 50-х гг. политики переселения в этот регион граждан из различных республик Советского Союза, главным образом, РСФСР и УССР. Отмечается, что районы с максимальной численностью украинского этноса исторически располагаются в северных районах Крымского полуострова, а с наименьшей - в южных. Как показало исследование, изменения в этнической структуре начали происходить после событий 2014 г. и вхождения Крыма в состав Российской Федерации, когда, согласно проведенной в 2014 г. переписи населения, численность украинцев в республике, по сравнению с 2001 г., сократилась почти на 9\%. Согласно проведенному анализу, если в период с 1989 по 2001 гг. максимальные масштабы сокращения численности украинского этноса происходили в центральной части Крымского полуострова, то в период с 2001 по 2014 гг. наибольшие масштабы снижения численности украинского этноса наблюдались в муниципальных образованиях северной части Республики Крым, что, по нашему мнению, объясняется, главным образом, оттоком населения с этих территорий, обусловленным негативной реакцией некоторых украинцев на события «Крымской весны» 2014 г.

Ключевые слова: Крымский полуостров, украинский этнос, население, демография, этническая структура.

1 Публикация подготовлена в рамках реализации ГЗ ЮНЦ РАН, № гр. проекта АААА-А19119011190184-2. 
Dmitry I. Uznarodov - Ph.D. in Political Science, Federal Research Centre the Southern Scientific Centre of the Russian Academy of Sciences, Rostov-on-Don, Russian Federation.

Узнародов Дмитрий Игоревич - кандидат политических наук, Федеральный исследовательский центр Южный научный центр Российской академии наук, г. Ростов-на-Дону, Российская Федерация.

A significant increase in the share of the Ukrainian ethnic group on the Crimean Peninsula in the $20^{\text {th }}$ century occurs in the post-war period. From 1939 to 1959 the Ukrainian population increased by almost $10 \%$, from 13.68 to $22.28 \%$ of the total recorded population of the peninsula [2,3]. Such changes in the ethnic structure of the region were due to the purposeful policy of the country's leadership, which sought to relocate to the territory of the peninsula as much of the population as possible from other Soviet republics (mainly the RSFSR and the Ukrainian SSR) in order to restore the region's economy weakened by the war, as well as to compensate for the demographic losses that also occurred in the region during the war years. During the war period, the decrease in the population of Crimea reached almost threefold values, and the determining factors here, in addition to losses during hostilities, were also the mass deportations of a number of peoples of the region, in particular, the Crimean Tatars, Bulgarians, Greeks, Armenians, Germans [1, p. 93]. Agriculture and industry were also in crisis. It was the large-scale resettlements from various republics of the Soviet Union that, in the opinion of the country's leadership, were supposed to solve the problem of restoring the Crimean economy.

The resettlement processes were regulated by the Decree of the State Defense Committee of August 12, 1944 "On the resettlement of collective farmers in the regions of Crimea." The number of immigrants was estimated at 51,000 people, both from various regions of the Ukrainian SSR and regions of the RSFSR (Krasnodar and Stavropol territories, Rostov, Voronezh, Bryansk, Kursk, Tambov, Oryol regions) [7, p. 59]. In addition to collective farmers, doctors, teachers, tractor drivers, combine operators and representatives of other professions also moved. The authorities provided displaced persons with various kinds of benefits, for example, a one-time cash allowance (2,500 rubles per family), exemption from government supplies and taxes [7, p. 59].

The "economic weakness" of the established collective farms and the underdevelopment of social infrastructure in the Crimean region led to the outflow of immigrants from the region. By October 1950, 57.8\% of resettled families left the Crimean region [7, p. 60]. These processes forced the country's leadership to re-engage the organization of resettlement to the Crimean region. According to the order of the Council of Ministers of the USSR dated April 8, 1950, the planned resettlement of citizens to Crimea was resumed. Most of the resettlement was carried out from the regions of the RSFSR (more than 1,500 farms) and the Ukrainian SSR (about 990 farms) [9]. The largest number of peasants from the Ukrainian SSR, according to the order, was to resettle the Vinnitsa region (about 300 families). Almost 200 families were to be resettled also in Kiev and Kamianets-Podilskyi regions. According to the Decree of the Council of Ministers of the Ukrainian SSR No. 1406 of June 13, 1951, about 1,000 families of collective farmers from Kiev, KamianetsPodilskyi, Chernigov, Zhitomir and Sumy regions were to be resettled to the Crimean region. Often, the resettlement was carried out not by individual families, but by whole collective farms at once [9]. During 1951, almost 4,600 people were sent from the Sumy and Vinnitsa regions to the territory of the Crimean Peninsula. In addition, already in the next 1952, about 780 families were sent to the Crimean region from the Kiev, KamenetsPodolsk, Sumy and Zhitomir regions of the Ukrainian SSR [9]. In total, in the period from 
1944 to 1953 from the Ukrainian SSR to the Crimean Peninsula 7586 collective farms were transferred [9, p. 97, 98, 99].

It was precisely the policy of resettlement of citizens from the Ukrainian SSR to the Crimean Peninsula, chosen by the Soviet authorities in the second half of the 40-s - early 50 -s and contributed to the formation of that percentage of the Ukrainian population in the ethnic structure of Crimea, which we could observe throughout the second half of the $20^{\text {th }}$ and early $21^{\text {st }}$ centuries. In the period from 1959 to 2001 the share of the Ukrainian population in the ethnic structure of the Crimean Peninsula ranged from 22.28 to $25.75 \%$ [3], [4], [5], [6]. The change in the share of the Ukrainian ethnic group in the structure of the population of the Crimean Peninsula occurred after the events of the "Crimean Spring" in 2014, when, according to the population census conducted in the same year, the number of Ukrainians in the republic decreased by almost $9 \%$ [8].

Table 1. The share of the Ukrainian ethnic group in the structure of the population of the Crimean Peninsula (excluding the city of Sevastopol) in the period from 1989 to 2014 [5,6,8]

\begin{tabular}{|l|l|l|l|}
\hline District / urban district & 1989 & 2001 & 2014 \\
\hline Alushta city district & 23,2 & 23,0 & 16,47 \\
\hline $\begin{array}{l}\text { Armyansk city district (in } 1989 \text { was part of the Krasnoperekopsky } \\
\text { district) }\end{array}$ & - & 36,2 & 29,52 \\
\hline Bakhchisarai District & 25,5 & 19,6 & 12,92 \\
\hline Belogorsk District & 22,9 & 16,2 & 10,10 \\
\hline Dzhankoy city district & 27,1 & 25,9 & 16,88 \\
\hline Dzhankoy region & 41,1 & 33,8 & 23,52 \\
\hline Evpatoria city district & 22,7 & 23,3 & 14,86 \\
\hline Kerch city district & 15,6 & 15,4 & 8,51 \\
\hline Kirov District & 22,4 & 17,6 & 10,68 \\
\hline Krasnogvardeysky District & 33,3 & 27,3 & 18,99 \\
\hline City district Krasnoperekopsk & 36,9 & 40,9 & 30,52 \\
\hline Krasnoperekopsk district & 48,7 & 43,4 & 32,54 \\
\hline Leninsky District & 28,1 & 22,9 & 15,15 \\
\hline Nyzhniohirskyi District & 33,9 & 28,8 & 19,54 \\
\hline Pervomaysky District & 43,6 & 37,9 & 28,63 \\
\hline
\end{tabular}




\begin{tabular}{|l|l|l|l|}
\hline RazdoInensky District & 45,0 & 40,1 & 30,29 \\
\hline Saky city district & 24,7 & 24,3 & 16,64 \\
\hline Saky District & 38,4 & 31,5 & 21,51 \\
\hline City district Simferopol & 22,1 & 21,3 & 13,12 \\
\hline Simferopol district & 30,7 & 23,5 & 15,03 \\
\hline Soviet District & 26,3 & 22,1 & 13,47 \\
\hline Urban district Sudak & 20,5 & 17,6 & 12,4 \\
\hline Feodosia city district & 17,3 & 18,8 & 12,24 \\
\hline Chernomorsky district & 31,7 & 29,3 & 18,87 \\
\hline Yalta city district & 25,8 & 27,6 & 19,27 \\
\hline
\end{tabular}

In 1989, according to the census data [5], the number of Ukrainians in Crimea (excluding the city of Sevastopol) was $26 \%$, in $2001-24.32 \%$ [6], in $2014-15.42 \%$ [8]. Historically, the maximum share of the Ukrainian ethnic group is observed in the northern regions of the Crimean Peninsula. Such districts include Dzhankoy, Krasnoperekopsk, Pervomaysky, Razdolnensky, as well as the city districts of Armyansk and Krasnoperekopsk. Another region with a large share of the Ukrainian population is historically the Saky District, located in the central part of the republic. Regions with a minimum share of the Ukrainian ethnos in the structure of the population are historically, mainly in the southern (urban districts of Kerch, Sudak and Feodosia, as well as Kirov district) and central (Belogorsk district, as well as the urban districts of Evpatoria and Simferopol) parts of the peninsula.

In the period from 1989 to 2001, the maximum scale of the decline in the number of the Ukrainian ethnic group occurred in Belogorsk (by 6.7\%), Dzhankoy (by 7.3\%), Krasnogvardeysky (by 6\%), Saki (by 6.9\%) and Simferopol (7.2\%) districts [5], [6]. An increase in the share of the Ukrainian population during this period was observed only in the urban districts of Evpatoria (by $0.6 \%$ ), Krasnoperekopsk (by 4\%), Feodosia (by 1.5\%) and Yalta (by $1.8 \%$ ) [5], [6].

In the period from 2001 to 2014, the municipalities of the Crimean Peninsula, in which the maximum scale of the decrease in the number of the Ukrainian ethnic group was observed, include Dzhankoy (by 10.28\%), Krasnoperekopsk (by 10.86\%), Razdolnensky (by $9.8 \%$ ), Saky (by 10\%), Chernomorsky (by 10.43\%) districts, as well as the city district of Krasnoperekopsk (10.38\%) [6], [8]. Unlike 2001, in 2014 there were no areas in which there was an increase in the number of the Ukrainian ethnic group.

As shown by the analysis, if in the period from 1989 to 2001 the maximum decrease in the number of the Ukrainian ethnic group occurred mainly in the regions of the central part of the Crimean Peninsula [5], [6], then in the period from 2001 to 2014 the largest decrease in the share of the Ukrainian population was observed in municipalities of the north of Crimea [6], [8]. It can be assumed that the largest outflow of the Ukrainian ethnos from the territory of the regions of the northern part of the Crimean Peninsula is mainly due to 
the events of the "Crimean Spring" of 2014, namely, the negative attitude of a certain part of the Ukrainian population towards the entry of Crimea into the Russian Federation. At the same time, it cannot be ruled out that the outflow of the Ukrainian ethnos from the territories of the northern regions of Crimea took place even before the events of the "Crimean Spring" of 2014, but it is impossible to assert with certainty, since, due to the lack of population censuses on the peninsula after 2001 and before 2014, we have no official statistics to support this version.

So, summing up, it should be noted that the percentage of the Ukrainian ethnic group in the structure of the population of the Crimean Peninsula, which we could observe in the period from 1989 to 2001, was formed as a result of the country's authorities in the late 40-s - early 50-s the policy of resettlement to this region of citizens from various republics of the Soviet Union, mainly the RSFSR and the Ukrainian SSR. If in 1939 the share of Ukrainians in the structure of the population of Crimea was $13.68 \%$, then in 1959 it was already $22.28 \%$. In subsequent years (in the period from 1959 to 2001), the share of the Ukrainian population in the ethnic structure of the Crimean Peninsula ranged from 22.28 (1959) to $25.75 \%$ (1989). The situation changed after the events of 2014 and the entry of Crimea into the Russian Federation, when, according to the 2014 population census, the number of Ukrainians in the republic, compared to 2001, decreased by almost $9 \%$. Historically, the regions with the maximum number of the Ukrainian ethnic group are located in the northern regions of the Crimean Peninsula, and with the smallest - in the southern regions. As shown by the study, in the period from 2001 to 2014 . The largest scale of decline in the number of the Ukrainian ethnic group was observed in the municipalities of the northern part of the Republic of Crimea, which, in our opinion, is mainly explained by the outflow of the population from these territories, caused by the negative reaction of some Ukrainians to the events of the Crimean Spring of 2014.

\section{Лumepamypa}

1. Бугай Н.Ф. Депортация народов Крыма. М.: ИНСАН, 2002. 240 с.

2. Всесоюзная перепись населения 1939 года. Национальный состав населения по регионам России. Крымская АCCP // Демоскоп Weekly. URL: http://www.demoscope.ru/weekly/ssp/rus_nac_39.php?reg=68 (дата обращения: 22.03.2021).

3. Всесоюзная перепись населения 1959 года. Городское и сельское население областей республик СССР (кроме РСФСР) по полу и национальности. Крымская область // Демоскоп Weekly. URL: http://www.demoscope.ru/weekly/ssp/resp_nac_59.php?reg=9 (дата обращения: 22.03.2021).

4. Всесоюзная перепись населения 1979 года. Городское и сельское население областей республик СССР (кроме РСФСР) по полу и национальности. Крымская область // Демоскоп Weekly. URL: http://www.demoscope.ru/weekly/ssp/resp_nac_79.php?reg=12 (дата обращения: 22.03.2021).

5. Всесоюзная перепись населения 1989 года. Распределение городского и сельского населения областей республик СССР по полу и национальности. Крымская область /l Демоскоп Weekly. URL: http://www.demoscope.ru/weekly/ssp/resp_nac_89.php?reg=11 (дата обращения: 22.03.2021).

6. Государственный комитет статистики Украины. Национальный состав населения, гражданство. Автономная республика Крым. URL: http://2001.ukrcensus.gov.ua/rus/results/nationality_population/nationality_popul1/ (дата обращения: 25.03.2021). 
7. Конониренко В.А. Переселение колхозников из России и Украины на постдепортационные территории Крыма в 1944-1953 годы // Известия Саратовского университета. Новая серия. Серия История. Международные отношения. 2017. Вып. 1. С. 59-63.

8. Перепись населения в Крымском федеральном округе // Федеральная служба государственной статистики.

URL: https://www.gks.ru/free_doc/new_site/population/demo/perepis_krim/perepis_krim.html (дата обращения: 25.03.2021).

9. Российский государственный архив экономики (РГАЭ). Ф. 5675. Оп. 1. Д. 678. Л. 98.

\section{References}

1. Bugay N.F. Deportatsiya narodov Kryma [Deportation of the peoples of Crimea]. Moscow: INSAN, 2002. 240 p. (In Russian).

2. Vsesoyuznaya perepis naseleniya 1939 goda. Natsionalnyy sostav naseleniya po regionam Rossii. Krymskaya ASSR [The All-Union Population Census of 1939. National composition of the population by regions of Russia. Crimean ASSR]. Demoscope Weekly. Available at: http://www.demoscope.ru/weekly/ssp/rus_nac_39.php?reg=68 (accessed 22 March 2021) (In Russian).

3. Vsesoyuznaya perepis naseleniya 1959 goda. Gorodskoye i selskoye naseleniye oblastey respublik SSSR (krome RSFSR) po polu i natsionalnosti. Krymskaya oblast [The All-Union Population Census of 1959. Urban and rural population of regions of republics of USSR (except RSFSR) by gender and nationality. Crimean region]. Demoscope Weekly. Available at: http://www.demoscope.ru/weekly/ssp/resp_nac_59.php?reg=9 (accessed 22 March 2021) (In Russian).

4. Vsesoyuznaya perepis naseleniya 1979 goda. Gorodskoye i selskoye naseleniye oblastey respublik SSSR (krome RSFSR) po polu i natsionalnosti. Krymskaya oblast [The All-Union Population Census of 1979. Urban and rural population of regions of republics of USSR (except RSFSR) by gender and nationality. Crimean region]. Demoscope Weekly. Available at: http://www.demoscope.ru/weekly/ssp/resp_nac_79.php?reg=12 (accessed 22 March 2021) (In Russian).

5. Vsesoyuznaya perepis naseleniya 1989 goda. Raspredeleniye gorodskogo i selskogo naseleniya oblastey respublik SSSR po polu i natsionalnosti. Krymskaya oblast [The AllUnion Population Census of 1989. Distribution of the urban and rural population of regions of republics of USSR by gender and nationality. Crimean region]. Demoscope Weekly. Available at: http://www.demoscope.ru/weekly/ssp/resp_nac_89.php?reg=11 (accessed 22 March 2021) (In Russian).

6. Gosudarstvennyy komitet statistiki Ukrainy. Natsionalnyy sostav naseleniya, grazhdanstvo. Avtonomnaya respublika Krym [State Statistics Committee of Ukraine. National composition of the population, citizenship. Autonomous Republic of Crimea]. Availableat: http://2001.ukrcensus.gov.ua/rus/results/nationality_population/nationality _popul1/ (accessed 25 March 2021) (In Russian).

7. Kononirenko V.A. Pereseleniye kolkhoznikov iz Rossii i Ukrainy na postdeportatsionnyye territorii Kryma v 1944-1953 gody [Resettlement of collective farmers from Russia and Ukraine to the post-deportation territories of Crimea in 1944-1953]. Izvestiya Saratovskogo universiteta. Novaya seriya. Seriya Istoriya. Mezhdunarodnyye otnosheniya. 2017. V. 1. pp. 59-63 (In Russian). 
8. Perepis naseleniya $\vee$ Krymskom federalnom okruge. Federalnaya sluzhba gosudarstvennoy statistiki [Population census in the Crimean Federal District. Federal State Statistics Service]. Available at: https://www.gks.ru/free_doc/new_site /population/demo/perepis_krim/perepis_krim.html (accessed 25 March 2021).

9. Rossiyskiy gosudarstvennyy arkhiv ekonomiki (RGAE) [Russian State Archive of Economics]. Fund 5675. In. 1. File 678. L. 98. 